[Original]

\title{
Semantic Change in English Intensifiers that Have Developed from a Prepositional Phrase and a Noun Phrase
}

\author{
Hiroshi OHASHI
}

Division of English Language, School of Medicine, University of Occupational and Environmental Health, Japan. Yahatanishi-ku, Kitakyusyu 807-8555, Japan

Abstract: In the advance of research in grammaticalization, there has been some inquiry into the development of English intensifiers. While most studies focus on the process of semantic shift from adverbs or adjectives that are the primary sources of intensifiers, little attention has been drawn to minor members of the category that have developed from a prepositional phrase or noun phrase. However, it is of great interest from the viewpoint of semantic change in general as well as that of grammaticalization and subjectification to examine what factors are engaged in the development of these intensifiers. This paper examines the development of indeed, a lot, a great/good deal, big time and all $X$ wants/ likes, and found that such mechanisms as metaphor, metonymy, conversational implicature, reanalysis, and the speaker's intention of producing illocutionary forces contribute to the semantic change of these intensifiers. Furthermore, as a theoretical implication of this study, it is observed that during the semantic shift that is regarded as a case of grammaticalization, most items have undergone subjectification, which gives support to the claim by E. C. Traugott, among others, that subjectification is found to take place concomitantly with grammaticalization.

Key words : intensifier, grammaticalization, semantic change, reanalysis, subjectification.

(Received 21 August 2007, accepted 17 October 2007)

\section{Introduction}

The aim of this paper is to observe the development of some minor intensifiers in the aspect of their having followed different processes from the majority of the members that have adjectives as their source. Another aim is to examine what factors are at work in the semantic shift from the original meaning. The organization of the discussion is as follows. First, in Section 1, I will make a very brief review of several previous studies in the development of intensifiers to share a general idea of what the development of intensifiers is like. This will 
serve as background for the subsequent discussion. Then, in Section 2, I will examine semantic shift in several intensifiers. Section 3 will consider some implications of the study of the development of intensifiers with regard to research in grammaticalization and subjectification. The last section presents a short summary of the discussion.

\section{Development of Intensifiers: Previous Studies ${ }^{* 1}$}

In this paper I use the term "intensifiers" to refer to certain kinds of adverbs that "serve to strengthen or weaken the meaning of a particular part of sentence" [1]. Among the members of the class, the items that will be dealt with here are included in what Quirk et al. [2] classify as "amplifiers" such as absolutely, completely, extremely, greatly, highly and a lot.

Intensifiers, as adverbs, form an open class, with new items always being created, and the primary sources of these new items are adverbs and adjectives. Therefore, it is natural that previous studies focused on the development and semantic shift of intensifiers from these primary sources.

For example, Partington [3] deals with intensifiers that have undergone the "modal-tointensifier" meaning shift and demonstrates the delexicalization process whereby items lose their independent meaning. The author has shown that intensifiers such as truly, genuinely, very, utterly, entirely and absolutely have had "some modal semantic content, through which speakers comment on their assessment of the truth of the matter under discussion or vouch for the sincerity of their words" [4] and how they have come to be used exclusively for adding emphasis.

Some items exhibit syntactic shift that corresponds to their semantic shift. Adamson [5] addresses the relation between the position of an adjective in a noun phrase that includes multiple adjectives and its meaning. Especially, she explored the meaning change of lovely and found that there has been syntactic change correlating to its semantic shift: from the original meaning that Dixon [6] classified as the HUMAN PROPENSITY meaning ("amiable"), through the PHYSICAL PROPERTY sense ("physically beautiful") and a VALUE adjective, which expresses speaker-response to the properties of the referent, and finally to its intensifier usage.

Lorenz [7] investigates the process of semantic shift in which English adverbs delexicalize and grammaticalize as they lose the original meaning that is derived from the corresponding adjectives.

As we can see from the brief look at the previous studies, they focus on the development from the major sources of intensifiers. However, there are several minor intensifiers that have different sources, and it would be of interest from the viewpoint of semantic shift to observe their development and the factors that are involved in the process. I will examine them in the next section. 


\section{Different Paths to Intensifiers}

In this section I will examine intensifiers that have developed the intensifier meaning through different pathways from the one that the majority of intensifiers have taken. The items that will be discussed are indeed, a lot, a good/great deal, big time and the phrase that will be schematically expressed as all $X$ wants/likes. Of these items, indeed was originally a prepositional phrase and has undergone semantic change, deriving the intensifier meaning and, further, the usage as a discourse marker, whereas the other items are regarded as having originally been noun phrases. As for indeed, there is already an inquiry into its semantic shift by Traugott and Dasher [8], and their discussion will be looked at in 2.1. Then in 2.2, I will examine the development of $a$ lot and a great/good deal, both of which have an original meaning that denotes number and amount. Section 2.3.1 is devoted to the investigation of the usages of a colloquial phrase, big time, referring to examples from the Oxford English Dictionary (OED) and corpora. The development of the intensifier all X wants/likes has been extensively discussed in Ohashi [9], and I will take a brief look at the research in the relevant respects in 2.3.2.

\subsection{From a Prepositional Phrase (PP) to an Intensifier}

Quirk et al. [10] classify indeed as an "emphasizer," which has "a reinforcing effect on the truth value of the clause or part of the clause to which they apply." According to their classification, "emphasizers do not require that the constituent concerned should be gradable," but when "the constituent emphasized is indeed gradable, the adverbial takes on the force of an intensifier." Indeed, as illustrated in the following example, is regarded as one of these emphasizers that have the same force as intensifiers:

(1) I indeed appreciate your help. ( = "I greatly appreciate your help.")

Therefore, I include indeed in the discussion of intensifiers.

Traugott and Dasher [8], in investigating the development of pragmatic meanings of indeed, distinguish three stages. In Stage 1, indeed retained its original form as a PP and had the adverbial meaning of "in action/practice," which they call indeed. While this original meaning is attested to have lasted until the 19th century, in some contexts the meaning "in action" "could invite the inference that the event was observable." [12] The inference, coupled with "the view that what is physically/empirically accessible is true," allowed the PP to acquire what Traugott and Dasher call "evidential" or "epistemic" meaning, that is, "in actuality, certainly."

This epistemic meaning as a "generalized conversational implicature," or GIIN, became a coded meaning or "semanticized" as an unambiguously abstract use, expressing the commitment of the speaker or writer (hereafter SP/W) to the truth of the proposition. This is what Traugott and Dasher call Stage II, in which the epistemic meaning of indeed ${ }_{2}$ was semanticized. Expressing a strong commitment to the truth of a proposition can invite an inference that the truth of the proposition is dubious. Early uses of indeed signaled $^{2}$ adversativity that arose from the contrast between the implicated doubt over the proposition and the strong confirmation of its truth by the speaker or writer. According to the authors, 
adversativity was lost in later development in some contexts, and a use as an "emphatic" degree adverb derived in such contexts, as illustrated in (2):

(2) This sleep is sound indeed.

In a different pathway, indeed has developed a use as a discourse marker. It originally appeared in clause-final or medial position, but as it came to appear clause-initially, it was sometimes used to convey a confirmatory answer to the question from the interlocutor, as illustrated in (3):

(3) Shallow: I dare say my cousin William is become a good scholar. He is at Oxford still, is he not?

Silence: Indeed, sir, to my cost. $\quad$ (1598 Shakespeare, Henry IV part 2, III. ii . 9) [14] Here, the primary function is "to signal additivity, somewhat like what's more." . This use

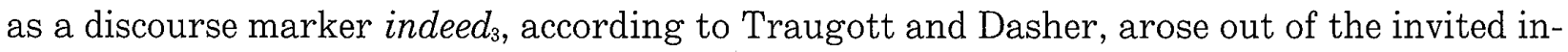
ference from the epistemic indeed in $_{2}$ that "if SP/W indicates commitment to the veridicality of "what follows indeed, "then he or she is committed to the belief that" its expression (verbal form) is better, more appropriate, etc. than the form of what precedes it. One of their examples of the semanticized indeed is $_{3}$ is quoted in the following:

(4) any a one that is not well, comes farre and neere in hope to be made well: indeed I did heare that it had done much good, and that it hath a rare operation to expel or kill diuers maladies.

(1630 Taylor, Penniless Pilgrimage, p. 131. C1) [15] Thus, the development of indeed is summarized as being from "in action" via "in actuality, certainly" to "what's more."

\subsection{From a Noun Phrase (NP) Denoting Number or Amount to an Intensifier}

\subsection{1 "A Lot"}

The earliest example of the adverbial usage of $a$ lot that is recorded in OED is shown in $(5):^{* 2}$

(5) There was plenty of cider - a lot too much, indeed.

(1886 Cornh. Mag. July 41) By then, the head noun of the phrase had undergone semantic bleaching. Lot was originally used to refer to an object used in deciding things. It derived metonymically related meanings such as the process of deciding and the result of deciding. It also expressed what falls to a person by the process, which can be a "share of property or destiny." Later it came to be used to refer to "plot of land and an article separated for sale, especially at an auction."

During the meaning extension, it derived a phrasal use in the form, "a lot of," referring to "a number of persons or things of the same kind or a quantity or collection of things, often with some degree of depreciation." The following sentence is the first example of its use recorded in OED:

(6) The next day the people, like a lot of wasps, were up in sundry places.

(c1575 J. Hooker, Life Sir P. Carew (1857) 49)

Out of this usage was derived the current use of referring to "a considerable number, quantity, and amount." OED's first example of this use is in (7):

(7) Lots of our Senators have of late been subject to the awful visitation. (1812 Spirit Pub.

Frnls. XVI. 191) 
From this sense, with no explicit mention of the intended people or things by the complement prepositional phrase, a lot has developed its intensifier meaning. During the development of the adverbial usage, $a$ lot at first denoted number or quantity of persons or things and then later came to refer to degree or extent of an action or process taking place. In considering the development it would be noteworthy to look at the examples of the intensifier and quantifier usages of a lot by Quirk et al. quoted in the following as (8):

(8) a. I like him a lot. ['to a great extent' - booster intensifier]

b. I paid him a lot for his work. ['a large amount' - quantifier]

c. I see him a lot.[ 'often' - frequency]

d. I slept a lot last night. ['a long time' - duration]

As they point out, intensifier adverbials cannot be the subject of a passive sentence, whereas quantifiers can, as illustrated in (9):

(9) A lot was paid him (by the new owner) for his work.

Here, the sentence that includes the attested quantifier can be seen as a transitional context where both the quantifier and intensifier interpretations are possible. Therefore, the sentence in (9) can be interpreted as meaning to pay "a large amount of money" as well as to do "a lot of paying." It is not difficult to imagine contexts in which both interpretations amount to describing the same situation. Therefore, we can suppose reanalysis is at work in this stage of the development of the intensifier use of a lot.

\subsection{2 "A Great/Good Deal"}

The adverbial usage of a great/good deal shows a similar process of development as that of a lot. The head noun deal originally had the meaning of "a part, portion, amount" and collocated with various adjectives such as good, great, vast or the like, as well as with poor, small or little. The earliest examples of a good deal, meaning "a considerable amount," and a great deal meaning "a large part, portion, allowance or amount (of anything), very much" that are cited in OED are shown below:

(10) Micel dæl bewylledes wæteres on hunizes godum dæle. $\quad$ (c1000 Sax. Leechd. II. 202)

(11) A great Deal of Lead

(1711 Hearne Collect. (Oxf. Hist. Soc.) III. 223)

The earliest example of the adverbial use of deal in OED is dated before 700, and the appearance is earlier than the earliest example of the nominal usage, which is dated before 800 . However, the second adverbial record is in 1225 and there are more examples in the 14th through 16th centuries. Considering these facts and the absence of examples for about 500 years, it would be reasonable to think that the adverbial usage became established around the 13 th and 14th centuries. In addition, this early adverbial use, which includes collocations such as "any deal," (meaning "to any extent") "some deal" ("to some extent, somewhat") and the like, became obsolete by the early 18 th century.

The current use of a great deal, meaning "to a great extent or degree, greatly, very much" appeared in the 16th century, while that of a good deal, meaning "to a considerable extent or degree, considerably" that is recorded in OED is dated in as late as 1887. Their earliest examples are shown in (12) and (13) and their examples from the present day usage are given in (14) and (15) below: 
(12) 1562 To lat down ane grete dele thair hie saillis.

(1562 Winzet Certain Tract. i. Wks. 1883 I . 3)

(13) 1887 I had traveled a good deal in earthquaking lands.

(1887 Sala in Illust. Land. News 19 Mar.)

(14) Their lives became a good deal more comfortable...

(15) He depended a great deal on his wife for support.

It would require more research on data to decide how this current adverbial usage has developed. Even if it came from analogy from the adverbial usage that went obsolete, where the obsolete adverbial usage came from should be addressed. The example cited below would suggest the pathway of development from a noun phrase to the adverbial interpretation:

(16) They've read an awful deal.

(1871 B. Taylor, Faust I . Prelude 3) According to OED, an awful deal is a noun phrase with "the thing referred to being implied or understood" and kept implicit. Obviously, however, it can invite reanalysis that the verb is intransitive and an awful deal is an adverb and there can be contexts in which these two interpretations show almost no difference in meaning.

\subsection{From a Noun Phrase to an Intensifier}

\subsection{1 "Big Time"}

The earliest examples of big time in OED are dated in 1863, as illustrated in the sentences in (17):

(17) a. The brigade was flying round, getting into line, drums beating and a big time generally.

(1863 O. W. Norton, Army Lett.(1903) 183)

b. We had big times that night for fires.

(1863 O. W. Norton, Army Lett.(1903) 183)

Here they mean "an excellent time" and they are transparent and compositional in meaning. Then, in the next example, dated in 1910, the noun phrase means "the best kind or highest rank," as shown in (18):

(18) The 'big time', as such theaters as Percy Williams' and Williams Morris' are termed.

(1910 R. Grau, Business Man in Amusement World 36)

This shift of meaning can be considered to be metonymically motivated, since a theater is a place to offer its audience an excellent time. In early examples in OED, big time seems to be used in reference to theaters and things related to them, such as acts and people who do performances there, as the following citations in (19) and (20) illustrate:

(19) Here are huge ledgers that tell the past movements and future bookings of every good act and every artist deemed worthy of 'good time'.

(1914 in Amer. Speech (1957) XXX II. 209)

(20) They buy and sell for all 'big time' acts and all 'big time' theaters.

(1914 in Amer. Speech (1957) XXX II. 209)

The fact that all the instances in the above examples appear in quotation marks suggests that the use of the phrase was not established yet. However, as it began to be used to refer to people in different fields, such as baseball players and newspersons, it appeared without quotation marks, as shown in (21) and (22):

(21) Like as not I will have to go back pitchin' baseball in some bush league on the account I 
am too old for the Big Time.

(1921 Collier's 25 June 3/3)

(22) Of the big time news-hawks who gathered in Keedora, only Matter remained.

(1935 M. M. Atwater Murder in Midsummer xxviii. 261)

This extension of usage can still be regarded as a case of metonymy, in which the phrase refers to a person who enjoys an excellent time or who has succeeded in life, hence meaning "the best kind or the highest rank" or "the top-ranker." Moreover, the phrase started to be used negatively to refer to, for instance, gangsters, racketeers and criminals, as shown in (23):

(23) Big time gangsters, racketeers, and the criminal aristocrats do not use narcotics.

(1936 Amer. Speech X I . 117)

Then it started to appear in an idiomatic phrase as "hit the big time," as shown in (24): (24) Scores of drummers who hit the big time play Premier. (1966 Crescendo Feb. 9(Advt.)) This collocation is very common in current usage and accounts for 22 out of the total of 197 instances in the Wordbanks Online (hereafter, WB), and 9 out of 120 appearances in the British National Corpus Online (hereafter, BNC). ${ }^{* 3}$

Common verbs that collocate with the phrase include make, reach and crack. The following examples in (25) to (27) are quoted from WB:

(25) Some other boys had the potential to make the big time but they turned to drinking or smoking and didn't take it seriously

(WBsunnow0075) $^{* 4}$

(26) Wing-half Normanton never reached the big time.

(WBtoday0124)

(27) Currie said the pool of talented players left behind by the Super League would be more than keen to play in a second-level competition for the chance to crack the big time.

(WBoznews0020)

Here the big time means "success" and still the verb phrases are fairly transparent and compositional in meaning.

In informal American speech, the phrase is used as an adverb in the form of big time and emphasizes "the importance or extent of something that has happened."[18] In some examples, it retains the original positive meaning about being successful. Look the examples in (28) and (29) from WB:

(28) At stand-off half, Ireland have selected David Humphreys, of Oxford University, who has been described as a "little gem" by Clive Woodward, the coach of London Irish.

"He's got it, big time," Woodward said.

Humphreys, who makes his Ireland debut, scored all of Oxford University's 19 points in the thrilling University match before Christmas.

(WBtimes0025)

(29) Desperate Ayr pitched Lee Power and Jim Dick in for Darren Henderson and Louis Donoway and went all out for the winner.

And it paid off big time with four minutes left as Millen converted Ian Ferguson's layoff.

(WBsunnow0012)

However, in the adverbial usage, the lexical meaning of the phrase is abstracted away and bleached to the extent that it is employed only for the purpose of emphasis, meaning "to a large degree," as evidenced in (30):

(30) "... The Arsenal fans deserve a Tony Adams who is giving, wanting and doing." 
Adams recovered big time.

So did Arsenal.

(WBsunnow0035)

In other examples, the phrase does not seem to assume its original positive connotation, or at least to have it considerably bleached, as illustrated in (31) to (33):

(31) Bad boys Charlie Sheen and Nicholas Cage ran up a $\$ 300$ bar tab between them in no time flat when the pair hit Beverly Hills for a night on the town.

And so happy with the service they got from there that they tipped her big time - a whopping $\$ 1000$ bill!

(WBoznews0014)

(32) Haami is big on reputation but little on appeal on the balance of his form.

Highly unlikely to stay.

High-Rise is the only unbeaten colt in the field and hails from a yard that knows how to improve its inmates big time.

(WBsunnow0067)

(33) In this big-hearted comedy drama, an assembly line worker wins a fortune shortly after learning she has the Big C. Dawn, marvellously played by Brenda Blethyn, decides she's going to boogie big time and goes on the razzle to Las Vegas with her best mate (Julie Walters in top form ).

(WBsunnow0088)

However, it seems that in many more examples big time is used to modify a verb phrase that describes negative processes, meaning "how bad or serious" the situation is [19]. Example sentences from WB that include the instances with this meaning are given below in (34) to (39):

(34) Phil hits the bottle big time.

(WBsunnow0005)

(35) I've been conned, gypped, sold a bill of goods big time.

(WBnpr0064)

(36) Carmen blows it big time in Western Australia and turns up as a federal minister.

(WBoznews0005)

(37) And he blew it and he lost out big time.

(WBukspoken0518)

(38) The pair, whose illicit canoodling allegedly contributed to Lenny's split from actress wife Lisa Bonet, fell out big time in 1993 after he wrote Justify My Love for her.

(WBsunnow0038)

(39) I went mad, berserk.

I lost my rag big time.

I was shouting and swearing.

(WBsunnow0063)

In this connection, it would be interesting to note the same kind of meaning shift, from positive or neutral to negative, in the noun phrase big deal. Compare the following examples in (40) and (41):

(40) This audition is a big deal for Joey.

(41) a. It's just a game. If you lose, big deal.

b. What's the big deal? It's only a birthday, not the end of the world.

As OED puts it, the original meaning of the phrase refered to "an important business transaction," which underwent abstraction and is used to describe "something important, exciting or satisfying." At the same time, the phrase is used ironically and it would be reasonable to think that as it is frequently put to that use, the implicature becomes gradually conventionalized and finally semanticized. 
I assume that the same type of pragmatic or rhetorical motivation is at work behind the meaning shift of the adverbial usage of big time that we have seen above.

\subsection{2 "All X Wants/Likes"}

There is another instance that has followed a path different from major intensifier adverbials. It is schematically described as all $X$ wants/likes, with $\mathrm{X}$ instantiated by a pronoun that refers to the subject of the sentence in which it appears. Although the phrase is a noun phrase in form that consists of the head pronoun all that is modified by the relative clause $X$ wants/likes, it functions as an adverb. I made an extensive examination of the phrase in Ohashi[9]. Therefore, I will review only the relevant argument in this section. First let us look at the adverbial usage of the phrase in the following examples:

(42) a. "But you can go out into the basin all you want," Mic broke in. (WB ukbooks0045)

b. Pound can talk all he likes about the cultural lag in America ... but he's got a 200 year political lag in himself.

$(\mathrm{BNC} \mathrm{AIB})^{* 5}$

(43) a. "You can defend him all you want, I really don't care," Nicole retorted.

(WBukbooks0070)

b. Garin shrugged mightily. "Disbelieve me all you want, but I know what I saw."

(WBukbooks0045)

For the sake of exposition, I will refer to the all $X$ wants/likes as AXW/L in the following discussion. As shown in the above examples in (42) and (43), AXW/L means "to the greatest extent" or "as much as one wants."

Regarding the path of its development from the referring noun phrase to the adverbial use, I hypothesized a "bridging" stage in which AXW/L allowed ambiguity between the NP and adverbial interpretations and therefore reanalysis was allowed to take place. The process is summarized in the following figure: ${ }^{* 6}$

(44) a. She did all we wanted.

(WB times0039)

b. Germany is now ready, we have been told, to give all we want in these respects.

(WB ukbooks0020)

(45) a. Buy all you want at the show without weighing yourself down. (WB ukephem0905)

b. You can say all you like, but it's clear that soul music is more popular than it has ever

I

$\left[[\mathrm{V}][\mathrm{AXW} / \mathrm{L}]_{\mathrm{NP}}\right]_{\mathrm{vP}}>$

$(44)$
II

$\left[[\mathrm{V}][\mathrm{AXW} / \mathrm{L}]_{\mathrm{NP} / \mathrm{Adv}}\right]_{\mathrm{VP}}>$

(45)
III

\section{$\left[[\mathrm{V}][\mathrm{AXW} / \mathrm{L}]_{\mathrm{Adv}}\right]_{\mathrm{vP}} /\left[[[\mathrm{V}][\mathrm{NP}]]_{\mathrm{vP}}[\mathrm{AXW} / \mathrm{L}]_{\mathrm{Adv}}\right]_{\mathrm{VP}}$}

Fig. 1. The development of $\mathrm{AXW} / \mathrm{L}$ 
been, worldwide.

(BNC AB3)

In Stage I, AXW/L has a nominal meaning that is illustrated in the example sentences in (44), while in Stage II, which is transitional, AXW/L is ambiguous, as shown by the examples in (45). ${ }^{* 7}$ What is interesting from the viewpoint of meaning shift is that the instances of AXW/L with the adverbial use show an extremely skewed distribution. The following table shows in what types of context $\mathrm{AXW} / \mathrm{L}$ appears in spontaneous discourse in $\mathrm{BNC}$ and WB:*8

Table 1. The number of context types in which AXW/L appears

\begin{tabular}{lccc}
\hline \multicolumn{1}{c}{ Context type } & All X wants & All X likes & Total \\
\hline Permission/Invitation(PI) & 3 & 1 & 4 \\
Acceptance/Concessive(AC) & 31 & 29 & 60 \\
Total & 34 & 30 & 64 \\
\hline
\end{tabular}

What could be surprising at first sight is that the adverbial intensifier instances do not appear in sentences that are used, for instance, to make statements or ask questions. A very small number of them are employed to give permission or offer an invitation, and the overwhelming majority of the instances are used to express what I call acceptance or concessivity. First let us look at examples that appear in the PI contexts: ${ }^{* 9}$

(46) "It is unbridled hypocrisy to say visual pollution is bad, but if you pay a fee you can pollute all you like," he said.

(WB oznews0008) (47) "But you can go out into the basin all you want," Mic broke in. (WB ukbooks0045) Here, the designated acts that are permitted to do or that one is invited to do are in the interest of the hearer. That is, in (46), the speaker says that people are permitted to spoil the view under a certain condition, and in (47), the speaker is giving permission to, or inviting the hearer to, wander within a specified area. Here, polluting the view is supposed to be in the interest of people or companies that are interested in putting up business signs, and wandering in the town is considered to be in the hearer's interest. In conveying the intended illocutionary force, the speaker uses AXW/L to underline the hearer's interest. In this way the use of $\mathrm{AXW} / \mathrm{L}$, which means "as much as X wants," is motivated by the purpose these sentences are employed for.

Next, let us turn to the instances that appear in the AC contexts. In the following examples, AXW/Ls appear in sentences that express acceptance:

(48) a. "Suit yourself. You can deny it to me all you like-I just hope you're not trying to deny it to yourself."

(BNC JY5)

b. "If you think it will help, repeat all you like," Ruth sighed.

(BNC JY4)

In (48a) the sentence that includes AXW/L refers to the hearer's denial of the speaker's suggestion and the speaker "accepts" what the hearer did. Here, the speaker is not actively or positively committed to encouraging the hearer to act in any way, nor does she believe that the act in question is in the hearer's interest. In this sense "acceptance" is meant to be used in a passive rather than active sense, and in a negative rather than positive sense. Likewise, in (48), Ruth is not urging the hearer to deny what she said, nor does she believe that denying 
is in his interest. Rather, as is suggested from the way she utters the sentence, she assumes resignation or indifference to what the hearer is going to do.

As the examples in (48) show, the acceptance sentence is often followed by a sentence in which the speaker states that the realization of the designated event will not change the existing situation or will fail in producing the intended effect. This type of flow of discourse is what is called "concessive." Look at the following example sentences:

(49) "Disbelieve me all you want, but I know what I saw... "

(WB ukbooks0045)

(50) She laughed with a toss of her silver hair.

"Well, mock me all you like, but I've never fancied being up this high."

(WB ukbooks0045)

In (49), referring to the hearer's attitude toward him, the speaker states that it will not affect what he believes in. Likewise, in (50) the speaker mentions the hearer's attitude toward her, and in the second sentence headed by the conjunction but, she implies that what the hearer does will not affect her present state of mind. In these examples, the sentences (hereafter, S1) that include AXW/L, combined with the sentences (hereafter, S2) that follow, establish discourse that is virtually equivalent to the concessive conditional sentence that often includes subordinators such as even if, or no matter how/what. In this respect, the imperative sentence $\mathrm{S} 1$ containing AXW/L corresponds to a concessive subordinate clause. Concessivity is sometimes not marked explicitly with but but rather contextually induced instead, as shown in the following example:

(51) "I'm sorry I pounced on you before," the dog told them.

"I get a little carried away sometimes."

"Think nothing of it," said the ducks.

"We understand completely. Pounce away all you like, we don't mind in the least."

(BNC CFJ)

If one describes a meaning of concessive conditional sentence as "EVEN IF S1, S2," in which the realization of $\mathrm{S} 1$ is assumed to be irrelevant to the realization of $\mathrm{S} 2$, the maximum effect of concessivity can be acquired by giving the exhaustive listing of possible S1s. Here, I consider the AXW/L is exploited to achieve that effect.

Seen from a different perspective, the concessive sentence involves "surprise," which is caused by an unexpected change of character of the situation expressed in the sentence. As for the relation between $\mathrm{S} 1$ and $\mathrm{S} 2$ in the above schema, following the event described by $\mathrm{S} 1$, the event denoted by the negation of $\mathrm{S} 2$ is normally expected to happen. However, what will happen is supposed to be the event described by $\mathrm{S} 2$, and therefore "surprise" is involved. In this sense, in uttering a sentence that contains $\mathrm{AXW} / \mathrm{L}$, the speaker is creating surprise by negating the expectation created by the preceding sentence.

In this connection, it would be noteworthy that all has been grammaticalized into part of the concessive connectives such as although and albeit. In addition, all often co-occurs with an idiomatic construction having said that, which expresses meaning similar to concessivity, illustrated in the following examples from BNC:

(52) a. Having said all that, there is usually something you can do to redeem a place.

(BNC ADK) 
b. Having said all that, you should keep your hands and nails in good condition for yourself and be proud of them rather than try to hide them away from view. (BNC C9P) These facts seem to suggest that the use of all in the concessive context is well motivated, and I claim that it is because of the function of all as expressing exhaustivity.

I have argued that the synchronic data suggests that the development of the intensifier usage of AXW/L has been promoted partly because of the meaning of its lexical head "all" and partly because of the way AXW/L is actually employed. In the very limited types of context in which it appears, the use of $\mathrm{AXW} / \mathrm{L}$ contributes to maximizing the effect of the illocutionary force of the sentence.

\section{Implications}

In this section I will briefly examine the implications that the study of the development of intensifiers whose origins are prepositional phrases and noun phrases can have with respect to the theories and hypothesis concerning semantic change, especially grammaticalization and subjectification.

\subsection{Grammaticalization}

The last two decades or so have seen a great advance in the study of grammaticalization, or grammaticization, as it is sometimes called, and there is a large amount of literature in this field. However, the definition of grammaticalization differs according to practitioners. Here I adopt the definition by Hopper and Traugott [20], as stated below:

(53) $[\mathrm{T}]$ he change whereby lexical items and constructions come in certain linguistic contexts to serve grammatical functions and, once grammaticalized, continue to develop new grammatical functions.

Then, there is a problem whether or not the development of an intensifier is a case of grammaticalization. The issue depends on one's notion of intensifiers. As I mentioned in Ohashi[21], if one considers the intensifier as a distinct grammatical category because of its very restricted function and abstract meaning, then the category shift that has accompanied its semantic shift can be regarded as a case of grammaticalization. On the other hand, if one thinks that the term "intensifier" refers to a function of a certain type of adverb and places significance on the fact that in some intensifiers the original meanings are easily traceable, then it may be reasonable to think the shift does not qualify for a case of grammaticalization. Here I tentatively regard the development of intensifiers as a case of grammaticalization, mainly because they have undergone considerable semantic bleaching and abstraction, and also because their grammatical function is very restricted. In addition, some function words such as because and although are fairly transparent in their semantic composition and also some intensifiers such as "honestly" in the following example have completely lost their original meanings:

(54) 'He honestly ( = really) deceived me,' 


\subsection{Subjectification}

If the development of intensifiers is considered to be a case of grammaticalization, another related topic comes in sight. Subjectification, which refers to a semantic change from objective to subjective meaning, is basically a distinct process from grammaticalization. However, as is widely attested in a lot of literature, including the work by Traugott[23-26], subjectification is found to take place concomitantly with grammaticalization. Look at the following statements by Traugott on subjectification in grammaticalization and on interpersonal function, which is a concept closely related to subjectification:

(55) It [subjectification in grammaticalization] is a gradient phenomenon, whereby forms and constructions that at first express primarily concrete, lexical and objective meanings come through repeated use in local syntactic contexts to serve increasingly abstract, pragmatic, interpersonal and speaker-based functions.

(56) "[I]nterpersonal" function can be interpreted as having the same meaning as the"expressive" function, in that both refer to the function of "expressing personal attitudes to what is being talked about, to the text itself, and to others in the speech situation."

If the "interpersonal" function that is a constituent element of subjectification is interpreted as meaning the "expressive" function, then the developing and acquiring the function of intensifiers can reasonably be thought of as a case of subjectification. It is because their primary and only grammatical function is emphasis, which is the manifestation of the speaker's attitude to what is being talked about. Moreover, some of the intensifiers examined in the previous sections exhibit further characteristics of subjectification. The case of indeed is an example from Traugott and Dasher [8], and they make a claim that the development summarized as from a "respect" adverbial ("in deed" = "in action, in actual practice") via an epistemic adverbial ("in actuality, certainly"), and to a discourse marker ("what's more") is a clear case of subjectification. Big time, as I already mentioned, shows a semantic extension in its use as an intensifier from its original positive meaning to negative meaning. I assume that this extension has been motivated by the pragmatic intention of irony, which is one of the classical means to be expressive. In addition, some examples of big time from spontaneous speech examples show that it is sometimes used like a kind of interjection and this can be seen as another way to illustrate its expressivity. As I discussed in Ohashi[9], the subjectivity of $\mathrm{AXW} / \mathrm{L}$ is obvious in the way it is used. As we saw in 2.3.2, the phrase is used to maximize the intended effects that the sentences that include it are employed for. The interpersonal function can be thought of as the manifestation of the speaker's wish to be expressive in the interaction with the hearer. 


\section{Summary}

In this paper I examined the development of several intensifiers that have followed different paths from those that the majority of intensifiers have. I have seen factors that work in the development process, such as metaphor, metonymy, (invited) inference, reanalysis, illocutionary forces and the speaker's intention to be expressive, inter alia. However, I have made only a cursory survey of limited facts in some part of the discussion. With regard to the development of $a$ lot and a good/great deal, I totally depended on the examples and description of OED. As for synchronic data, I drew on examples from large corpora, but regarding the current usage of big time, I have only made an unsystematic observation. These issues merit a more precise and systematic investigation.

Notes

${ }^{*} 1$. The survey in this section is based on the review in Section 2.1 of Ohashi [9] and I would like to refer the reader to it for detailed information.

*2. All the OED example sentences are cited from Oxford English Dictionary 2nd edition on CD-ROM and do not appear here with page references.

*3. I assume that the difference of the percentage in appearance comes from the difference in organization and speech genre of the two corpora. WB contains 2.5 times as much spoken English, and the phrase appears mainly in informal speech and discourse.

*4. The words and the numbers that follow WB refer to the category that the example belongs to in the corpus.

*5. The letters that follow $B N C$ refer to the category that the example belongs to in the corpus.

*6. The schema in Fig. 2 is the same as that in (17) in Ohashi[9] with changes regarding the numbers of the example sentences.

*7. Regarding the interpretation of the instances of AXW/L in this stage, see the discussion in Section 3 of Ohashi[9].

*8. Table 1 is quoted from Ohashi[9].

*9. Permission/invitation and acceptance/concessive types of context are so termed following the names Huddleston and Pullum [29] used in classifying the use of the English imperative sentences.

\section{References}

1. Declerck R (1991): A Comprehensive Descriptive Grammar of English. Kaitakusha, Tokyo p 230

2. Quirk R, Greenbaum S, Leech G \& Svartvik J (1985): A Comprehensive Grammar of the English Language. Longman, Harlow pp 589-597

3. Partington A (1993): Corpus evidence of language change: The case of the intensifier. In Text and Technology: In Honour of John Sinclair. (Baker M, Tognini-Bonelli E \& Francis G ed) John Benjamins, Amsterdam/Philadelphia pp 177-192

4. Partington A (1993): Corpus evidence of language change: The case of the intensifier. In Text and Technology: In Honour of John Sinclair. (Baker M, Tognini-Bonelli E \& Francis G ed) John 
Benjamins, Amsterdam/ Philadelphia p 181

5. Adamson S (2000): A lovely little example: Word order and category shift in the premodifying string. In Pathways of Change:Grammaticalization in English. (Fischer O, Rosenbach A \& Stein D ed) John Benjamins, Amsterdam/Philadelphia pp 39-66

6. Dixon RMW(1982): Where Have All the Adjectives Gone? Mouton de Gruyter, Berlin $256 \mathrm{pp}$

7. Lorenz G (2002): Really worthwhile or not really significant?: A corpus-based approach to the delexicalization and grammaticalization of intensifiers in modern English. In New Reflections on Grammaticalization. (Wischer I \& Diewald G ed) John Benjamins, Amsterdam/Philadelphia pp 143-161

8. Traugott EC \& Dasher RB(2002): Regularity in Semantic Change. Cambridge University Press, Cambridge pp 159-165

9. Ohashi $H$ (2006): The development of an English intensifier phrase: A corpus-based study. English Linguistics 23(2): 403-432

10. Quirk R, Greenbaum S, Leech G \& Svartvik J (1985): A Comprehensive Grammar of the English Language. Longman, Harlow p 583

11. Quirk R, Greenbaum S, Leech G \& Svartvik J (1985): A Comprehensive Grammar of the English Language. Longman, Harlow p 586

12. Traugott EC \& Dasher RB (2002): Regularity in Semantic Change. Cambridge University Press, Cambridge $\mathrm{p} 160$

13. Traugott EC \& Dasher RB (2002): Regularity in Semantic Change. Cambridge University Press, Cambridge $\mathrm{p} 163$

14. Traugott EC \& Dasher RB (2002): Regularity in Semantic Change. Cambridge University Press, Cambridge $\mathrm{p} 164$

15. Traugott EC \& Dasher RB (2002): Regularity in Semantic Change. Cambridge University Press, Cambridge $\mathrm{p} 165$

16. Quirk R, Greenbaum S, Leech G \& Svartvik J (1985): A Comprehensive Grammar of the English Language. Longman, Harlow pp 602-603

17. Sinclair J ed (2006): Collins COBUILD Advanced Learner's English Dictionary, 5th Edition. Harper Collins Publishers, Glasgow p 358

18. Sinclair J ed (2006): Collins COBUILD Advanced Learner's English Dictionary, 5th Edition. Harper Collins Publishers, Glasgow p 128

19. Summers D director (2000): Longman Advanced American Dictionary. Pearson Education Limited, Harlow p 122

20. Hopper P \& Traugott EC (2003): Grammaticalization. 2nd ed, Cambridge University Press, Cambridge $\mathrm{p} x \mathrm{v}$

21. Ohashi $H$ (2006): The development of an English intensifier phrase: A corpus-based study. English Linguistics 23(2): 407

22. Greembaum S (1969): Studies in English Adverbial Usage. Longman, London p 86

23. Traugott EC (1982): From propositional to textual and expressive meanings: Some semanticpragmatic aspects of grammaticalization. In Perspectives on Historical Linguistics (Lehmann WP \& Malkiel Y ed). John Benjamins, Amsterdam pp 245-271

24. Traugott EC (1988): Pragmatic Strengthening and Grammaticalization. BLS 14: 406-416

25. Traugott EC (1995): Subjectification in grammaticalization. In Subjectivity and Subjectivisation (Stein D \& Wright S ed). Cambridge University Press, Cambridge pp 31-54

26. Traugott EC (2004): Historical pragmatics. In The Handbook of Pragmatics (Horn LR \& Ward GL ed). John Benjamins, Amsterdam/Philadelphia pp 539-561

27. Traugott EC (1995): Subjectification in grammaticalization. In Subjectivity and Subjectivisation (Stein D \& Wright S ed). Cambridge University Press, Cambridge p 32 
28. Traugott EC (1982): From propositional to textual and expressive meanings: Some semanticpragmatic aspects of grammaticalization. In Perspectives on Historical Linguistics (Lehmann WP \& Malkiel Y ed). John Benjamins, Amsterdam p 248

29. Huddleston RD \& Pullum GK (2002): The Cambridge Grammar of the English Language. Cambridge University Press, Cambridge p 931

前置詞句と名詞句から発達した英語強意詞の意味変化

大橋＼cjkstart浩

産業医科大学 医学部 英語教室

要

旨：文法化研究の進展にともない英語強意詞の発達に関する研究も行われてきた. 多くの先行 研究では強意詞の主な供給源である副詞や形容詞からの意味変化の過程に焦点が当てられ ているが, 一方, 前置詞句や名詞句から発達した強意詞にはほとんご注意が向けられてこな かった．しかし, 意味変化の観点からのみならず文法化や主観化の面から考えてもこれらの 強意詞の発達にどのような要因が関与しているかという点は非常に興味ある課題である. 本論文では indeed, a lot, a great/good deal, big time, all X wants/likesという強意詞 の発達を考察し,メタファー(隠喻), メトニミー (換喻), 会話の含意, 再分析, 発話の力を産 出しようとする話者の意図などの要因がその意味変化に関与していることを明らかにした. さらに, ここで論じた意味変化を文法化の例と考えると,多くの語句は主観化しており, 文 法化に伴って意味の主観化が起こるとするトローゴットなどの主張を支持するという理論 的意味合いを持つ.

キーワード : 強意詞, 文法化, 意味変化, 再分析, 主観化.

J UOEH (産業医大誌) 29 (4) : 391-406 (2007) 